TEME, г. XLIV, бр. 3, јул - септембар 2020, стр. 901-912

Прегледни рад https://doi.org/10.22190/TEME181020061K

Примљено: 20. 10. 2018.

UDK 338.48:005

Ревидирана верзија: 29. 8. 2019.

Одобрено за штампу: 1. 10. 2020.

\title{
ПРОЦЕС КАНДИДОВАЫА КАО ТЕХНИКА ПРОДАЈЕ У ДЕСТИНАЦИЈСКОМ МЕНАЏМЕНТУ - ПРИМЕР СРБИЈЕ КАО КОНГРЕСНЕ ДЕСТИНАЦИЈЕ У РАЗВОЈУ ${ }^{a}$
}

\author{
Игор Ковачевић", Бојан Зечевић, Александар Ђорђевић
}

Универзитет у Београду, Економски факултет, Београд, Република

Србија

*igor.kovacevic@ekof.bg.ac.rs

\begin{abstract}
Апстракт
Своје активности дестинацијске менаџмент-организације обављају за интерес и рачун стејкхолдера дестинације. Њихове активности односе се на стварање што бољих услова дестинације за задовољење захтева туриста као потрошача. Са друге стране, једна од кључних активности, које претходе задовољењу потреба туриста, односи се на технику продаје дестинације - процес истицања кандидатуре. Предмет овог истраживања управо се односи на теоријско идентификовање и разумевање самог процеса, различитих фаза и специфичности, а релевантан резултат истраживања, који има значајну практичну примену, показао је да у ситуацијама када конгресни биро дестинације, као дестинацијска менаџмент-организација, води процес кандидовања, успешност добијања конгреса је на много већем нивоу, и то у чак $80 \%$ случајева испитаног узорка.
\end{abstract}

Кључне речи: дестинацијски менаџмент, ДМО, кандидатура, продаја, конгресни биро.

\section{BIDDING AS A SALES TECHNIQUE IN DESTINATION MANAGEMENT - EXAMPLE OF SERBIA AS AN EMERGING CONGRESS DESTINATION}

\begin{abstract}
Destination management organizations are implementing their activities for the benefit and interest of the destination stakeholders. Those activities are influencing the creation of the better destination conditions needed for satisfying the needs and wants of tourists as final consumers. On the other hand, one of the key activities, that is the basis for satisfying tourist needs, is a destination sales technique - the bidding process. The research subject
\end{abstract}

\footnotetext{
а Средства за реализацију истраживања обезбеђена су од стране Министарства просвете, науке и технолошког развоја.
} 
here focuses on the theoretical identification and understanding of the bidding process, various phases and characteristics, and the relevant results that have significant practical application show that in situations where convention bureau, as a destination management organization, leads the bidding process, success rate is on a much higher level in $80 \%$ of research cases.

Key words: destination management, DMO, bid, sales, convention bureau, CVB.

\section{УВОД}

Једна од основних техника продаје активности носилаца дестинацијског менаџмента и дестинацијског маркетинга, али и хотела и конгресних центара, јесте „истицање кандидатуре”. Истицање кандидатуре можемо посматрати као процес тендера путем ког организатор конгреса настоји да одабере конгресну дестинацију за свој наредни догађај. Са аспекта дестинације, истицање кандидатуре је процес прилагођавања понуде дестинације заснованој на формалним и неформалним критеријумима и улазак у процес отвореног надметања са осталим дестинацијама. У пракси се може увидети да развијене конгресне дестинације (висок ниво квалитета конгресне инфраструктуре и висок ниво дестинацијског менаџмента) карактерише снажно коришћење технике истицања кандидатуре као проактивног начина приступа клијентима и начина одржавања конкурентске предности. Носиоци ових активности су конгресни бирои, који представљају форму дестинацијских менаџмент-организација. Иако значајна активност у области конгресног туризма, истицање кандидатуpe је предмет истраживања ограниченог броја аутора, што у исто време представља и проблем, јер недостаје потпуни научни оквир, али и предност, јер постоје могућности за значајно напредовање у истраживањима.

\section{УЛОГА ДЕСТИНАЦИЈСКИХ МЕНАЦМЕНТ-ОРГАНИЗАЦИЈА}

Дестинацијски менаџмент је процес планирања, истраживања, имплементације, контроле и евалуације дестинацијских програма усмерених на потребе туриста (Morrison, 2013). Дестинацијска менаџмент-организација (ДМО) ствара услове у којима гост може задовољити своје потребе и очекивања, те алате који усмеравају успешан развој саме дестинације (Ritchie \& Crouch, 2003). ДМО игра кључну улогу у развоју, маркетингу и менаџменту дестинације (Hvass, 2014). ДМО је одговорна за аспекте као што су повећања броја туриста, продужавања њиховог задржавања у дестинацији и повећања потрошње туриста током боравка у дестинацији (Pike \& Page, 2014), што представља сложен процес управљања, где продаја дестинације има најважнију улогу (Pike, 2004). Кључ успеха ДМО огледа се у 
стварању атмосфере сарадње између кључних стејкхолдера дестинација (Fyall, Garrod, \& Wang, 2012; Beritelli, 2011). Управо термин продаја подразумева активности ДМО на координирању понуде читаве дестинације приликом заједничког представљања тржишту. Можемо закључити да ДМО раде у интересу читаве дестинације и представника понуде и за рачун њих. Изазов се јавља у ситуацијама када дестинације морају да балансирају читавим скупом различитих комуникативних, рецептивних и посебно атрактивних фактора, као и стејкхолдерима (Hvass, 2014). ДМО морају да балансирају поменутим ресурсима и искуствима у процесу паковања „производа” приликом продаје клијентима и директним корисницима, при чему мора постојати баланс између свих учесника понуде. На овај начин ДМО ствара услове дугорочно одрживе конкурентности саме дестинације.

Као две кључне компетенције успешних ДМО, можемо истаћи маркетинг, који је усмерен на остваривање екстерно оријентисаних перформанси, и координацију стејкхолдера на нивоу дестинације, која је основ остваривања интерних перформанси (Presenza, Sheehan, $\&$ Ritchie, 2005). Као показатељ укупне успешности ДМО користи се „квалитет искуства посетиоца” (Ritchie \& Crouch, 2005). ДМО асистира представницима тражње у разумевању дестинације, атракција дестинације, и пре свега искуства које делегати могу да стекну током боравка у дестинацији (Fenich, 2004). Координирањем представника понуде и интегрисањем њихових индивидуалних капацитета и услуга у јединствену понуду дестинације ствара се конкурентска предност на стално растућем међународном конгресном тржишту (Moscardo, 2011).

Активности ДМО могу се финансирати на неколико начина. ДМО може у потпуности бити буџетска институција, приватно власништво или може функционисати на платформи приватно-јавног партнерства. Конгресни биро је доминантна форма дестинацијске менаџмент и маркетинг организације (Getz \& Sheehan, 1998). Конгресни биро, као ДМО, има улогу активног промотера дестинације и свих ресурса дестинације, организаторима конгреса, групама и индивидуалним туристима (Bramwell \& Rawding, 1994).

\section{ИСТИЦАЊЕ КАНДИДАТУРЕ КАО ТЕХНИКА ПРОДАЈЕ}

Истицања кандидатуре је уводна фаза саме организације догађаја, која обухвата, поред елемената као што су дефинисање идеја, студије оправданости, и саму припрему и представљања кандидатуpe (Westerbeek et al., 2006). Процес истицања кандидатуре је формални покушај привлачења одређеног догађаја и добијања права организације (Getz, 2003). Процес истицања кандидатура је део одређених политика дестинације у којима одређене интересне групе и елите по- 
стају уверени у значај догађаја и, сходно томе, настоје да добију одређену подршку на широј друштвеној основи (Hiller, 1999). Садржи неколико базичних корака (Ingerson \& Westerbeek, 2000): формирање тима за процес кандидовања, припремања одговарајућег документа за кандидовање, званична предаја документа за кандидовање и лобирање, те проглашавање будућег организатора догађаја. Носилац укупног процеса истицања кандидатуре је дестинацијска менаџменторганизација (ДМО), односно конгресни биро, али то може бити и конгресни центар или конгресни хотел. Документ за кандидовање садржи објашњење свих аспеката који ће се имплементирати приликом организација догађаја у односу на услове које клијент захтева. Истицање кандидатуре врши се кроз тзв. документ за кандидовање (енгл. bid book), који мора да прикаже дестинацију у односу на захтеве клијената, при чему начин писања и структурирања документа за кандидовање мора бити објективан и фокус мора бити на фактима и јасним аспектима (Catherwood \& Van Kirk, 1999). Након званичне предаје или слања документа, следи процес лобирања. Лобирање се односи на подизање свести клијента да је конкретна дестинација у процесу кандидовања за домаћина једног од наредних скупова и, сходно томе, у неким случајевима, разрађена стратегија лобирања остварује веће ефекте у односу на технички квалитетну кандидатуру (Catherwood \& Van Kirk, 1992). Основне специфичности истицања кандидатуре односе се на следеће (Getz, 2003):

- Најчешће се примењује код догађаја који су по броју делегата већи и који се организују на мећународном нивоу;

- Категорије догађаја за које се дестинације могу кандидовати се у дестинацији дешавају само једном (или постоји мала вероватноћа да се врате после одређеног броја година);

- Власник догађаја има дискреционо право доделе организације догађаја одређеној дестинацији;

- Истицање кандидатуре је процес који захтева посебне ресурсе и експертизу, у поређењу са уобичајеним продајним напорима;

- Постоји одређени ризик да се изгуби кандидатура у корист неке друге дестинације.

Елементи успешне кандидатуре могу се поделити на (Wilkinson, 1988): техничке елементе (локација догађаја, конгресни капацитет, буџет догађаја, предложени датуми, план промоције), подржавајуће елементе (подршка, смештајни капацитет, остале услуге) и културне елементе (карактеристике града, промоција кроз град). Претходно уочене елементе је пожељно укључити како би кандидатура била целокупна, али за успешност кандидатуре, поред испуњења кључних елемената, неопходно је да се у обзир узму и критични фактори успеха процеса кандидовања које можемо поделити на (Westerbeek, Turner, \& 
Ingerson, 2002): примарне факторе (политички, економски фактори, инфраструктурни и социо-културни фактори) и секундарне факторе (конкурентно и пословно окружење). У примарне факторе можемо укључити и елементе попут изградње односа, посвећеност процесу кандидовања, гарантовања додатне вредности и одређене оставштине конгреса локалној дестинацији.

\section{СПЕЦИФИЧНОСТИ ПРОЦЕСА КАНДИДОВАЊА У ОДНОСУ НА ТРЖИШНИ СЕГМЕНТ}

Највећи део тражње у конгресном туризму је скоцентрисан на два значајна тржишна сегмента, а то су корпорације и асоцијације. Догађаји асоцијација се разликују по својим карактеристикама од догађаја корпорација (Chon, 1991), што подразумева и различит приступ организатора конгреса (Grimaldi, 1997). У највећем броју случајева, код тржишта међународних асоцијација отворени позив заинтересованим дестинацијама (са условима и критеријумима) налази се на сајту асоцијације или је послат свим чланицама, што подразумева да свака, или условно свака земља чланица, може да се укључи у процес надметања за организацију наредног догађаја асоцијације. Уколико се ради о тржишту корпоративних састанака, процедура пријаве и улазак у процес кандидовања нису транспаренти, јер се ради о интерним документима и потребама корпорације, те процес кандидовања добија полујавни карактер, односно у највећем броју случајева корпорације дистрибуирају формално формулисан захтев (Request for proposal, RFP) на свега неколико адреса, чиме се процес ограничава на унапред префериране дестинације. У случају корпорација, процес истицања кандидатура траје знатно краће, јер се укупан процес доношења одлука у највећем броју случајева одвија у периоду до једне године, имајући у виду годишње буџетско финансирање (Weber, 2001). Овде је реч о мањим групама и коришћењу капацитета најчешће једног хотела, те дестинацијске менаџмент-компаније (Destination management company, DMC), или хотели самостално могу да одговоре и прилагоде понуду, док је у случају асоцијација носилац процеса кандидовања у највећем броју случајева конгресни биро. Истицање кандидатуре је проактивна техника која показује професионалност дестинацијског менаџментсистема у пракси (Doussa \& Koutoulas, 2009). Успешне кандидатуре обухватају понуду која је прилагођена захтевима - и формалним и неформалним - тражње и клијената. 


\section{ГЛОБАЛНО ТРЖИШТЕ КОНГРЕСНОГ ТУРИЗМА И ПОЗИЦИЈА СРБИЈЕ}

Према подацима Светске конгресне асоцијације (ICCA, 2016; ICCA 2017), током 2015. године одржано је 12.212 конгреса асоцијација које испуњавају међународне критеријуме, док је у 2016. години тај број износио 12.588 догађаја. У посматраном периоду Србија је заузела 48, односно 42. место у свету, док је Београд заузео 51, односно 46. позицију у свету, са аспекта броја међународних конгреса које је организовао. У посматраном периоду бележи се и 10 година од оснивања посебног ентитета у форми дестинацијске менаџмент-организације - Конгресног бироа Србије, чији је задатак развој и маркетинг Србије, као конгресне дестинације на глобалном нивоу. Током 2015. и 2016. године, Конгресни биро Србије ушао је у 38 процеса кандидовања Србије као домаћина некој од међународних догађаја асоцијација, а од поменутог броја, 16 догађаја је потврђено (Конгресни биро Србиje, 2016).

\section{ИСТРАЖИВАЊЕ ПРОЦЕСА КАНДИДОВАЬА СРБИЈЕ КАО ДЕСТИНАЦИЈЕ У РАЗВОЈУ}

Циљ овог истраживања је да се утврди релевантност тока истицања кандидатуре и процеса, који су дефинисани кроз теоријски оквир у прегледу литературе, за Србију као конгресну дестинацију у развоју, односно за Конгресни биро Србије као дестинацијску менаџмент-организацију. У периоду истраживања од 24 месеца (јануар 2015 - децембар 2016. године) анализирани су процеси кандидовања за 10 догађаја међународних асоцијација, где је Конгресни биро Србије био носилац самог процеса. Анализа подразумева да је праћен сваки корак процеса кандидовања од почетне фазе до предаје документа и његове презентације (у складу са процесима дефинисаним у прегледу литературе). Ово је подразумевало практичан пролазак (теренско истраживање) кроз сваку од фаза у директном контакту са стејкхолдерима и на страни тражње и на страни понуде. Временски оквир од две године захтевао је значајно улагање ресурса истраживача. Од укупног броја анализираних процеса, три се односе на светске асоцијације које у обзир узимају ротацију дестинација организатора на светском нивоу, док се остали анализирани процеси односе на седам асоцијација које у обзир узимају само ротацију на нивоу европских земаља. Сви истраживани процеси кандидовања захтевали су формално достављање докумената за кандидовање (бид документа) од стране заинтересованих дестинација, иако нису сви имали јасно дефинисане и транспарентне критеријуме одлучивања. Сви анализирани конгреси окупљају минимум 800 делегата. Свака кандидатура 
је привукла неколико земаља кандидата, а свака земља је представљена од стране једног стајкхолдера из следећих категорија (укупно 26 стејкхолдера): 14 конгресних бироа (локални или национални, и то заједно са домаћом асоцијацијом), 10 домаћих асоцијација које су имале самостални наступ и 2 конгресна центра (и то заједно са домаћом асоцијацијом).

\section{РЕЗУЛТАТИ ИСТРАЖИВАЬА}

Иако по броју међународних конгреса и стању конгресне инфраструктуре Србија спада у категорију дестинација у развоју, можемо закључити да активности, структура и приступ процесима кандидовања показују да је степен имплементације дестинацијског менаџмента на високом нивоу. У свим наведеним примерима, процедура која је теоријски дефинисана кроз преглед литературе практично је и потврђена, односно, остварена је на предвиђен начин.

Укупно 60\% кандидатура потврђено је за оне дестинације где је конгресни биро био носилац процеса кандидовања, 10\% кандидатура потврђено је за дестинације где је конгресни центар водио процес самостално и $30 \%$ за дестинације где су локалне асоцијације наступале самостално. Како Србија спада у категорију конгресних дестинација у развоју, посебно је анализирана успешност у процесу кандидовања у ових 10 студија случаја. Степен успешности је 60\%, при чему само у једном случају критеријуми одлучивања нису били у потпуности транспарентни.

Табела 1. Узорак истражсивања са критеријумима одлучивања

\begin{tabular}{|c|c|c|c|c|}
\hline Име конгреса & $\begin{array}{l}\text { Број } \\
\text { делегата }\end{array}$ & $\begin{array}{l}\text { Година за } \\
\text { коју се } \\
\text { дести- } \\
\text { нација } \\
\text { кандидује } \\
\end{array}$ & $\begin{array}{l}\text { Постојање } \\
\text { критеријума } \\
\text { одлучивања / } \\
\text { носилац } \\
\text { победничке } \\
\text { кандидатуре }\end{array}$ & $\begin{array}{l}\text { Интернет презентације } \\
\text { међународних } \\
\text { асоцијација } \\
\text { (власника догађаја) }\end{array}$ \\
\hline $\begin{array}{l}\text { Конгрес светске } \\
\text { асоцијације } \\
\text { перинаталне } \\
\text { медицине }\end{array}$ & 2000 & 2018. & $\begin{array}{l}\text { Познати у } \\
\text { потпуности / } \\
\text { Конгресни биро } \\
\text { Србије }\end{array}$ & https://www.wapm.info/ \\
\hline $\begin{array}{l}\text { Конференција } \\
\text { светске } \\
\text { федерације } \\
\text { истраживача у } \\
\text { позоришту }\end{array}$ & 1100 & 2019. & $\begin{array}{l}\text { Нису били } \\
\text { транспарентни / } \\
\text { Конгресни биро } \\
\text { Србије }\end{array}$ & https://www.iftr.org/ \\
\hline $\begin{array}{l}\text { Светски конгрес } \\
\text { ортопеда }\end{array}$ & 4000 & 2019. & $\begin{array}{l}\text { Познати у } \\
\text { потпуности / } \\
\text { Конгресни } \\
\text { центар Мускат }\end{array}$ & http://www.sicot.org/ \\
\hline
\end{tabular}


Табела 1. Узорак истражсивања са критеријумима одлучивања (наставак)

\begin{tabular}{|c|c|c|c|c|}
\hline Име конгреса & $\begin{array}{l}\text { Број } \\
\text { делегата }\end{array}$ & $\begin{array}{l}\text { Година за } \\
\text { коју се } \\
\text { дести- } \\
\text { нација } \\
\text { кандидује } \\
\end{array}$ & $\begin{array}{l}\text { Постојање } \\
\text { критеријума } \\
\text { одлучивања / } \\
\text { носилац } \\
\text { победничке } \\
\text { кандидатуре } \\
\end{array}$ & $\begin{array}{l}\text { Интернет презентације } \\
\text { међународних } \\
\text { асоцијација } \\
\text { (власника догађаја) }\end{array}$ \\
\hline $\begin{array}{l}\text { Конференција } \\
\text { европске } \\
\text { асоцијације за } \\
\text { практично } \\
\text { стрељаштво }\end{array}$ & 1500 & 2019. & $\begin{array}{l}\text { Познати у } \\
\text { потпуности / } \\
\text { Конгресни биро } \\
\text { Србије }\end{array}$ & $\begin{array}{l}\text { https://www.ipscmatches. } \\
\text { org }\end{array}$ \\
\hline $\begin{array}{l}\text { Конгрес европске } \\
\text { асоцијације } \\
\text { неурохирурга }\end{array}$ & 2000 & 2019. & $\begin{array}{l}\text { Познати у } \\
\text { потпуности / } \\
\text { Асоцијација } \\
\text { неурохируга } \\
\text { Велике } \\
\text { Британије }\end{array}$ & https://www.eans.org/ \\
\hline $\begin{array}{l}\text { Конгрес } \\
\text { европског } \\
\text { удружења } \\
\text { контрабасиста }\end{array}$ & 1000 & 2020. & $\begin{array}{l}\text { Нису били } \\
\text { транспарентни / } \\
\text { Асоцијација } \\
\text { контрабасиста } \\
\text { Скандинавије }\end{array}$ & https://basseurope.org/ \\
\hline $\begin{array}{l}\text { Конгрес европске } \\
\text { асоцијације } \\
\text { паразитолога }\end{array}$ & 850 & 2021. & $\begin{array}{l}\text { Познати у } \\
\text { потпуности / } \\
\text { Конгресни биро } \\
\text { Србије }\end{array}$ & http://www.eurofedpar.eu/ \\
\hline $\begin{array}{l}\text { Конгрес европске } \\
\text { асоцијације } \\
\text { рехабилитационе } \\
\text { медицине }\end{array}$ & 850 & 2020. & $\begin{array}{l}\text { Познати у } \\
\text { потпуности / } \\
\text { Конгресни биро } \\
\text { Србије }\end{array}$ & http://www.esprm.net/ \\
\hline $\begin{array}{l}\text { Конгрес европске } \\
\text { асоцијације } \\
\text { микрохирургије }\end{array}$ & 800 & 2021. & $\begin{array}{l}\text { Познати у } \\
\text { потпуности / } \\
\text { Удружење } \\
\text { микрохирурга } \\
\text { САД }\end{array}$ & $\underline{\text { http://www.efsm.eu/ }}$ \\
\hline $\begin{array}{l}\text { Конгрес } \\
\text { удружења } \\
\text { цистичне фиброзе }\end{array}$ & 2200 & 2018. & $\begin{array}{l}\text { Познати у } \\
\text { потпуности / } \\
\text { Конгресни биро } \\
\text { Србије } \\
\end{array}$ & $\underline{\text { https://www.ecfs.eu/ }}$ \\
\hline
\end{tabular}

Извор: сопствено истраживање

\section{ДИСКУСИЈА}

У анализираном узорку конгресни биро је своје активности обављао у име и за рачун локалне асоцијације и дестинацијских стејкхолдера (хотели, конгресни центри). У случају када је конгресни центар водио процес кандидовања, конгресни биро дестинације 
у којој се налази конгресни центар уопште није споменут. У ситуацијама када су локалне асоцијације саме водиле процес кандидовања, испоставило се да нису биле свесне функција и активности конгресних бироа као дестинацијских менаџмент-организација, односно можемо закључити да у конкретним дестинацијама конгресни бирои не постоје или не обављају функцију кандидовања као алата продаје дестинацијског менаџмента. Резултати истраживања показују да се $80 \%$ процеса кандидовања заснива на јасно и јавно дефинисаним захтевима и критеријумима клијената, а од тог броја се $50 \%$ односило на техничке елементе (конгресна инфраструктура, хотели), 35\% на подржавајуће критеријуме и $15 \%$ на различите карактеристике дестинације. У $20 \%$ случајева нису постојали транспарентно комуницирани критеријуми одабира дестинације. У овим случајевима поставља се питање основа доношења одлука, али и релевантност уочених корака процеса кандидовања. Иако су сви спроведени у пракси на начин како је литература предвидела, неопходно је у даљим истраживањима размотрити да ли су поједине фазе сувишне и на који начин реаговати на ситуације када критеријуми доношња одлука нису транспарентни.

\section{ОГРАНИЧЕЊА ИСТРАЖИВАЬА}

Величина узорка свакако представља ограничавајући фактор. Повећањем величине узорка јасније и прецизније се могу анализирати кораци самог процеса истраживања и уочити правилности. Увођењем у анализу и активности конгресних бироа равијених дестинација може се побољшати квалитет закључака које доносимо на основу корака у процесу кандидовања, као и на основу успешности самог процеса. Са продужавањем периода истраживања, односно посматрања, добиле би се објективније оцене.

\section{ЗАКљУЧАК}

Конгресни биро, као дестинацијска менаџмент-организација, своје функције у највећој мери може операционализовати кроз проактиван однос ка тржишту, а то се постиже кроз имплементацију технике продаје - истицањем кандидатуре. Резултати истраживања дају јасан практичан допринос за носиоце туристичке политике и менаџмента дестинације, јер је закључено да, уколико је конгресни биро носилац процеса кандидовања, постоји много већа шанса да дестинација добије организацију конгреса, него уколико самостални носиоци понуде (као што су конгресни центри или хотели) приступе кандидовању, или ако сама локална удружења самостално приступе. Разлог томе је што конгресни бирои по природи ствари покривају 
сложене аспекте дестинације, а не само партикуларне аспекте, те да се због позиције и искуства бирои сматрају објективним партнером. На овај начин творци туристичке политике развоја на нивоу дестинација могу да закључе неоходност имплементације адекватног система дестинацијског менаџмента и активности продаје. Такође, рад представља један од ретких који се односе на технику продаје у оквиру дестинацијског менаџмента „истицање кандидатуре”, због чега је научни допринос рада јасан, јер употпуњује уочене празнине и даље промовише дестинацијски менаџмент као област истраживања.

\section{ЛИТЕРАТУРА}

Beritelli, P. (2011). Cooperation among prominent actors in a tourist destination. Annals of Tourism Research, 38(2), 607-629.

Bramwell, B. \& Rawding, L. (1994) Tourism Marketing Organizations in Industrial Cities: Organizations, Objectives and Urban Governance, Tourism Management 15(6), 425-430.

Catherwood, D. \& Van Kirk, R. (1992). The Complete Guide to Special Event Management: Business Insights, Financial Advice, and Successful Strategies from Ernst \& Young. John Wiley \& Sons Inc, USA.

Catherwood, D. \& Van Kirk, R. (1992). The Complete Guide to Special Event Management: Business Insights, Financial Advice, and Successful Strategies from Ernst \& Young. John Wiley \& Sons, Inc, USA.

Цhon, K.S. (1991). Meetings management and hospitality/tourism industry. Aix-enProvence: Centre des Hautes Etudes Touristiques.

Doussa, M. \& Koutoulas, D. (2009) Benchmarking Destination Marketing Organisations for the Purpose of Optimising their Operation: The Case of Convention Bureaux. Proceedings of the 4th International Scientific Conference "Contemporary development in tourism, travel and hospitality", April 3-5, Rhode Island, Greece.

Fyall, A., Garrod, B., \& Wang, Y. (2012). Destination collaboration: A critical review of theoretical approaches to a multi-dimensional phenomenon. Journal of Destination Marketing \& Management, 1(1-2), 10-26.

Fenich, G. (2004). Meetings, Expositions, Events \& Conventions: An Introduction to the Industry, 2nd Edition, Pearson Prentice Hall, USA.

Getz, A. \& Sheehan, L. (1998). Roles, issues, and strategies for convention and visitors' bureaux in destination planning and product development: a survey of Canadian bureaux. Tourism Management, 19(4), 331-340.

Getz, D. (2003). Bidding on Events: Identifying Event Selection Criteria and Critical Success Factors. Journal of Convention \& Exhibition Management, 5(2), 1-24.

Grimaldi, L. (1997). Both sides now. Meetings and Conventions, 32(2), 65-71.

Hall, C.M. (1998). Introduction to tourism: Divelopment, dimensions and issues, 3rd edition, Pearson.

Hiller, H. H. (1999). Toward an urban sociology of mega-events Constructions of Urban Space, Vol. 5, 181-205.

Hvass, K.A. (2014). To fund or not to fund: A critical look at funding destination marketing campaigns. Volume 3, Issue 3, October 2014, Pages 173-179.

Ingerson, L., \& Westerbeek, H. (2000). Determining key success criteria for attracting hallmarksporting events. Pacific Tourism Review, 3(4), 239-253. 
Morrison, A. M. (2013). Marketing and managing tourism destinations. New York, USA: Routledge.

Moscardo, G. (2011). The role of knowledge in good governance for tourism. In E. Laws, H. Richins, J. Agrusa, \& N. Scott (Eds.), Tourist destination governance: Practice, theory and issues (pp. 67e80). Cambridge, Oxfordshire: CABI.

Pike, S. (2004). Destination Marketing Organisations. Elsevier, UK.

Pike, S. \& Page, S.J. (2014). Destination Marketing Organizations and destination marketing: A narrative analysis of the literature, Tourism Management, 41, 202-227.

Presenza, A., Sheehan, L. \& Ritchie, J.R.B. (2005). Towards a model of the roles and activities of destination management organizations, Journal of Hospitality, Tourism and Leisure Science 3, 1-16.

Ritchie, J. R. B., \& Crouch, G. I. (2003). The competitive destination: A sustainable tourism perpective, Wallingford: CABI Publishing.

Weber, K. (2001). Meeting planners' use and evaluation of convention and visitor bureaus. Tourism Management, 22, 599-606.

Westerbeek, H., Smith, A., Turner, P., Emery, P., Green, C. \& Leeuwen, L. V. (2006). Managing sport Facilities and Major Event. London: Routledge.

Westerbeek, H., Turner, P. \& Ingerson, L. (2002). Key success factors in bidding for hallmark sporting events. International Marketing Review, 19(3), 314-316.

Wilkinson, D. (1988). Workbook: Event Management Planning Process. Event Management and Marketing Institute, Ontario, Canada.

ICCA Statistics Report, Country \& City Rankings, 2016 and 2017.

\title{
BIDDING AS A SALES TECHNIQUE IN DESTINATION MANAGEMENT - EXAMPLE OF SERBIA AS AN EMERGING CONGRESS DESTINATION
}

Igor Kovačević, Bojan Zečević, Aleksandar Đorđević

University of Belgrade, Faculty of Economics, Belgrade, Serbia

\begin{abstract}
Summary
One of the basic sales technique-activities performed by destination management is the bidding process. It the formal activity of attracting a specific event and winning the organizational right. The bidding process involves activities such as creating a bidding team, the preparation of the bid book, the bid submission, presentation, lobbying and the decision-making process. The bidding process is based on the creation of the so-called bid document that needs to present a destination in relation to the client's requests. Additionally, it needs to be based on key facts and clear aspects, needs to be objective, and the leader of the process is a destination management organization - the convention bureau. Key elements of the bidding process can be divided into technical elements, supporting elements and cultural elements. However, in order to make results positive, it is necessary to involve critical success factors of the bidding process which are divided into primary and secondary factors. Research proved that in $70 \%$ of cases, a bid has been confirmed when convention bureau led the process, in $10 \%$ when the convention center led the process independently, and in $20 \%$ when local associations had their own process. In the first case, the convention bureau led the process on the behalf and for the benefit of the
\end{abstract}


local association and destination stakeholders (hotels, congress centers, etc.). The results of the research also demonstrate that $80 \%$ of the bidding process is based on the transparent and public published requests, while in $20 \%$ of cases there were no clear guidelines on the decision-making criteria. In situations where requests were public, $50 \%$ were focused on technical elements (congress infrastructure, hotels), 35\% on supporting elements and $15 \%$ on other various destination elements. Convention bureau, as a destination management organization, manages activities based on the proactive market approach, and that is achieved though selling activities, where bidding represents the most important activity. 